\title{
Factors Influencing Credit Demand among Household Non-Agriculture Enterprises in Malawi
}

\author{
Meya Mkandawire, Xiaohong Duan* \\ School of Economics and Management, China University of Geoscience, Wuhan, China \\ Email:meyamkandawire@yahoo.co.uk, ‘duan_xiaohong@126.com
}

Received 10 March 2016; accepted 24 April 2016; published 27 April 2016

Copyright (C) 2016 by authors and Scientific Research Publishing Inc.

This work is licensed under the Creative Commons Attribution International License (CC BY). http://creativecommons.org/licenses/by/4.0/

\section{c) (i) Open Access}

\begin{abstract}
This study examined factors that influenced households with non-agriculture enterprises to borrow funds as capital for their enterprises in Malawi. Additionally, the study aimed at classifying households as borrowers and non-borrowers, but also classified these households according to their liquidity status in which credit could be a component. The primary data for this study was sourced from the Integrated Household Panel Survey (IHPS) conducted in 2013 by the National Statistics Office of Malawi. Out of 4000 households that formed the sample, 1249 households were reported to own an enterprise; representing $31.23 \%$ of the overall sample. The logit model was used in this study and results showed that borrowing was influenced by age of household head, size of household, poverty status of household and enterprise sector. Furthermore, liquidity status was influenced by education attained by household head and poverty status of household. Poverty status of the households was found to influence both borrowing and liquidity non-constraint of households in Malawi. The paper shows the need to focus on poor households that are unable to support their enterprises with personal savings. In addition, policy makers must design programs that will provide credit to poor households operating manufacturing type of enterprises.
\end{abstract}

\section{Keywords}

Microfinance, Credit, Micro-Enterprise, Poverty

\section{Introduction}

Micro and small enterprises (MSE) are very important to the development of many countries as they contribute to employment generation, poverty alleviation, rural development, and overall economic development [1] [2].

\footnotetext{
Corresponding author.
}

How to cite this paper: Mkandawire, M. and Duan, X.H. (2016) Factors Influencing Credit Demand among Household Non-Agriculture Enterprises in Malawi. Open Journal of Business and Management, 4, 312-321. 
Malawi is a poverty ridden country, which has households that are unable to meet their daily requirements. Various causes of poverty in Malawi have been identified that include poor agriculture production that has resulted into food insecurity, the HIV/AIDS pandemic that has crippled the work force, and limited off-farm employment and rapid population growth [3]. Poverty in Malawi is associated with households that lack adequate income, employment opportunities, sufficient food, entrepreneurship spirit and credit opportunities (Machinjili et al., 1999). One way of reducing poverty in Malawi has been the promotion of MSE's to reduce the unemployment rate and increase household incomes. It has been estimated that Malawi has 433,078 enterprises that are owner run thus they do create employment; 324,922 enterprises create employment of between 1 and 100 employees, of which $81 \%$ employ 1 - 4 people, 17\% employ 5 - 20 people and 2\% employ 21 - 100 people [4].

Despite the MSE's in Malawi playing an important role for household's economic development, there are many challenges and constraints that prevent their growth. Lack of credit (has to be capital) to provide the MSE's with capital to invest in an activity so as to increase their income is acknowledged as a major challenge in Africa [5]. The lack of capital by smaller firms and poverty stricken households is made worse by the tight liquidity constraints that they encounter [6]. Liquidity in developing countries is the major character of household's financial wealth that can be used to support it and invest various economic ventures [7]. There is a consensus in literature that MSE's do not utilize formal financial services provided by banking institutions, due to collateral requirements that they cannot meet. The other option is for these MSE's to obtain credit from informal financial sources that include relatives, money lenders, friends and rotating savings. However, these informal sources are characterized by high credit costs that are reflected by high interest rates than those offered by formal sources. The use of informal credit sources limits these enterprises to adequately invest in productive activities.

Since 1994, when Malawi attained a multi party political system, there had been a reported increase in the number of MSE's due to the removal of various government restrictive policies [4]. To support MSE's, the GoM adopted the MSE policy in 1998 and special attention had also been shown by handing the management and responsibility of MSEs in the country to the ministry responsible for Industry, Trade and Private Sector Development. Through the policy and institutional setup, GoM has provided an environment for promoting microfinance institutions and the regulatory framework to promote best practice approaches in provision of financial services. Microfinance institutions provide loans to the poor that lack savings and capital to invest in productive income generating activities. These microfinance institutions offer credit through simple mechanisms that demand simple forms of collateral (or no collateral) and use lower interest rates. Despite these efforts, it has been established that the smaller the business in terms of number of employees, the less likely that the owner has or uses formal financial services to manage their finances.

Households are the smallest units that can be targeted in poverty alleviation efforts, because they together form a community. Empowering households to engage in self-employment and undertake productive incomegenerating activities through investing in MSE's is a welcome effort to reduce the poverty burden the households. Thus providing households with credit specifically to business investment is a requirement if this strategy is to be achieved. Despite the increase in microfinance programmes in Malawi, there is a need to design them in a manner that they respond to the credit demand from households that operate or intend to operate MSE's [8]. Using data from the Integrated Household Survey three (IHS3), this paper determined factors that influence households demand for credit to use as enterprise capital in Malawi. Furthermore, this paper assessed the role of credit relative to the liquidity status of the borrower.

\section{SME's Credit Demand}

Capital for SME's is required at the initial stage of an enterprise start-up and at the point where the enterprise is needed to grow [9]. Capital provides SME's the muscle and flexibility to allow a manager to implement investment decisions to improve profitability on an enterprise. Households that operate SME's can obtain capital from internal or external sources. The internal sources may include personal savings of household members or profits from the enterprise; external sources of capital consist of formal money lending institutions like commercial banks and microfinance institutions, but also from informal sources like friends, relatives and local money lenders. The challenge for poor households and MSE's is that they are liquidity constrained, which means they operate with a negative budget to allow them to save or invest in the enterprise. The alternative is external sources of capital that provide the needed capital for investment. As already alluded to, collateral requirements hinder 
households and MSE's to obtain credit from banks, while high credit costs associated with informal sources do not provide a better option. Microfinance institutions have been introduced in less developed countries, such as Malawi, to respond to the credit demand created by the poor that cannot afford formal or informal credit sources [10]. Microfinance refers to the provision of financial services (including credit provision that is central to this study) for low-income households and micro entrepreneurs for productive purposes [11]. The financial services need to be packaged in a fashion that reflects the demand from the households and microenterprises.

Demand for credit among households has been discussed by various literatures [2] [12]-[15], which suggest that demographic and social economic factors are important to determine whether a household will source credit or not. Furthermore, Abdulsaleh and Worthington [9] reviewed literature on enterprise financing and observed the enterprise characteristics also affect credit decision making. The choice by a household with an enterprise to borrow is thus influenced by enterprise characteristic, demographic and social economic factors.

In most developing countries men have an advantage over their female counterparts with regards to owning and successfully operating income generating activities. This is attributed to the social norms and roles that relegate women to performing household chores while men go into both farm and non-farm enterprises [16]. Women usually lack collateral to get credit from formal sources, but are also afraid with the prospect of failing the payback the loan [17]. Bendig [18] hypothesized that male headed households were more likely to source credit services; Rand [14] observed that male owned enterprises in Vietnam obtained credit more frequently than those owned by females. Age of household head is a factor that can determine credit demand for a household enterprise, because young household heads are not risk averse and may not be interested in obtaining loans [19]. Furthermore the older household heads may have experience on the importance of owning a vibrant household enterprise; they may also have more resources that can be used as collateral to obtain loans. Zeller [12] estimated factors that determine credit demand in Madagascar and results showed that the older a household head was, the likely they were to demand credit. Thus it can be hypothesized that older household heads participate in the credit market than their younger counterparts. Marital status of a household head may also influence credit demand by mainly working in favor of the married, with those that are widows or separated suffering emotional stress to support their families and even societal humiliation [20]. Education is an essential catalyst of development and is usually used as a measure of human capital, with those that attain higher education being more flexible to venturing in development focused efforts [21]. Jabbar [13] in their assessment of factors influencing livestock farmers obtain credit in four sub-Saharan countries observed that education level attained by household head positively influenced credit demand. Fanwell [22] determined household factors that influenced credit borrowing in Malawi, and found that family size had a positive and significant influence. Larger family size exerts pressure on the household financial resources, making them unable to save funds for capital [23]; larger sized households are more likely to borrow. Household income level is a factor that has been considered as an influence to credit demand. Households that have higher income levels are more likely to seek credit because they have confidence of paying back from future incomes or from their savings, which makes them risk takers. However, another explanation shows that, when individual's income is very low, the marginal utility of consumption is very high, leading to high demand of credit [24].

Abdulsaleh and Worthington [9] reviewed literature on enterprise financing and observed the enterprise characteristics also affect credit decision making. These enterprise characteristics include the size of firm, age of enterprise, geographical location, and industry sector. Age of the enterprise influences the credit demand of a firm, as young enterprises do not prefer to obtain credit because they lack collateral and even trust from the credit suppliers to provide the loans. Younger enterprises, usually those less than four years old, are in most need of credit to support the establishment of their enterprises, and the best option for credit are informal sources [25] [26]. The size of enterprise in Malawi entails that a micro-enterprise is that which employs four people or has an equivalent number of four people working even though not employed [4]. The size of an enterprise reflects the high level of production that the enterprises would achieve, hence making them suitable to demand and access credit. The industry sector in which an enterprise belongs (i.e. manufacturing or services for this study) determines how an enterprise organizes its finances [27]. A manufacturing enterprise credit demand would be for a long term period, which is usually associated with breaking even in the production process that may involve purchase of machinery and associated equipment. While services enterprises would prefer a short term loan that responds to an immediate need. In these scenarios the demand for credit and source would be different. The location where a household is found in relation to the nearness of banks, MFIs and other money lenders is also a factor that determines credit demand [28]. Rand [29] examined which firm characteristics determined credit 
access to Vietnamese household enterprises and found that location had a significant positive influence on credit demand. Similarly, Fatoki and Asah [26] showed that the location of enterprises to their banks and MFI's is an advantage, because they can develop a strong lending bank with those financial institutions.

\section{Methodology}

\subsection{Data Source}

The primary data for this study was source from the Integrated Household Panel Survey (IHPS) conducted in 2013 by the National Statistics Office of Malawi. The IHPS was designed to collect data on households interviewed during the third Integrated Household Survey (IHS3), which was conducted in 2010. The IHS is employed by the GoM every five years with the objective of monitoring and evaluating the living conditions of households in the country. The IHPS focuses on households as research units and assesses the changing conditions affecting each individual. The IHPS was conducted at the national level and covered various topics, which included household enterprises and their lending behaviors. The IHPS results contain detailed information on households the three regions of Malawi, including the urban and rural parts. The IHPS has a sample size of 4000 households living in Malawi. Out of 4000 households that forms the sample, 1249 households were reported to own an enterprise; representing $31.23 \%$ of the overall sample. This sample is composed of households that owned non agriculture enterprises, with $49 \%$ based in rural areas and $26 \%$ residing in urban areas.

\subsection{Data Analysis}

The household's decision to borrow or not for the purpose of investing in a non agriculture enterprise is a binary choice, which can be represented as a qualitative variable whose range is limited. To analyze such binary decisions for households discrete choice models have been used by various choice related studies; commonly used models are logit and probit models [12] [13] [15]. Goswami et al., [30] notes that there is no theoretical explanation that supports the use of logit over probit or vice versa. However, the logit model is a mostly preferred because researchers find it mathematically easy to understand and interpret [31]. The logit model has been used in this study, to determine factors that influence households to demand credit to support their enterprises. Furthermore, Jabbar et al., [13] observed that it is not adequate to classify units as merely borrowers or non-borrowers, but rather it is important to also classify them based on why some used credit and others did not when liquidity constraint is put into perspective. Liquidity constrained units are those in need of more funds, while liquidity non-constrained units are those that have funds to ably invest in their enterprises. In this study, liquidity non-constrained households were those had ability to save from their current income and liquidity constrained included households that could not save from their incomes. In this case, the logit model was also used to determine factors influencing the liquidity status of the households. The dependent variables were binary in nature: borrower $=1$, non-borrower $=0$; liquidity non-constrained $=1$, liquidity constrained $=0$. Table 1 shows a summary and descriptive of factors that were used in this study. Gender, education, marital status, wealth and enterprise sector were entered in the model as dummy variables. The other variables namely age, household size, location of household, and enterprise age were entered as continuous variables. Data analysis for this study was done using STATA/SE version 12 (http://www.stata.com).

\section{Results and Discussion}

\subsection{General Descriptive Statistics}

This study used enterprise characteristic, demographic and social economic factors to determine factors that influence borrowing among households with enterprises. A total of 238 (19 percent) of households with an enterprise had ever borrowed for the purpose of investing in their business venture. Additionally, 488 (39 percent) households were liquidity non-constrained. With regards to the specific independent variables, households were mainly male headed with a proportion of 81 percent; while a similar trend was observed for borrowers and liquidity non-constrained that had 78 percent and 85 percent of male headed households respectively (Table 1). Mukherjee and Benson [3] also observed most households were headed by males, this is normal with Malawian societies that are headed by males and it is embedded in the cultures of the country.

Average age of household heads was 40 years old, which was almost similar to the borrowers (40.5 years old) 
Table 1. Descriptive statistics of the variables used in the logit model.

\begin{tabular}{|c|c|c|c|c|c|c|}
\hline \multirow[b]{2}{*}{ Variables } & \multirow[b]{2}{*}{ Unit of Measurement } & \multicolumn{5}{|c|}{ Average } \\
\hline & & Total & Borrower & Non-Borrower & $\begin{array}{c}\text { Liquidity } \\
\text { Non-Constrained }\end{array}$ & $\begin{array}{l}\text { Liquidity } \\
\text { Constrained }\end{array}$ \\
\hline Gender & Dummy, 1 for Male, 0 for female & $\begin{array}{c}0.81 \\
(0.39)\end{array}$ & $\begin{array}{c}0.78 \\
(0.417)\end{array}$ & $\begin{array}{c}0.82 \\
(3.83)\end{array}$ & $\begin{array}{c}0.85 \\
(0.361)\end{array}$ & $\begin{array}{c}0.79 \\
(0.406)\end{array}$ \\
\hline Age & Years & $\begin{array}{c}40.2 \\
(13.1)\end{array}$ & $\begin{array}{c}39 \\
(11.56)\end{array}$ & $\begin{array}{c}40.5 \\
(13.39)\end{array}$ & $\begin{array}{l}39.55 \\
(11.88)\end{array}$ & $\begin{array}{c}40.62 \\
(13.77)\end{array}$ \\
\hline Marital Status & Dummy, 1 for married, 0 for other & $\begin{array}{c}0.8 \\
(0.397)\end{array}$ & $\begin{array}{c}0.78 \\
(0.417)\end{array}$ & $\begin{array}{c}0.81 \\
(0.393)\end{array}$ & $\begin{array}{c}0.82 \\
(0.385)\end{array}$ & $\begin{array}{c}0.79 \\
(0.405)\end{array}$ \\
\hline Household Size & Number of people & $\begin{array}{c}5.2 \\
(2.329)\end{array}$ & $\begin{array}{l}5.47 \\
(2.24)\end{array}$ & $\begin{array}{c}5.15 \\
(2.35)\end{array}$ & $\begin{array}{l}5.17 \\
(2.36)\end{array}$ & $\begin{array}{c}5.24 \\
(2.31)\end{array}$ \\
\hline Education & $\begin{array}{l}\text { Dummy, } 1 \text { for primary level and } \\
\text { above, } 0 \text { for other }\end{array}$ & $\begin{array}{c}0.5 \\
(0.497)\end{array}$ & $\begin{array}{c}0.43 \\
(0.496)\end{array}$ & $\begin{array}{c}0.45 \\
(0.498)\end{array}$ & $\begin{array}{c}0.6 \\
(0.49)\end{array}$ & $\begin{array}{c}0.35 \\
(0.476)\end{array}$ \\
\hline Wealth & Dummy, 1 for poor, 0 for other & $\begin{array}{c}0.6 \\
(0.496)\end{array}$ & $\begin{array}{l}0.53 \\
(0.5)\end{array}$ & $\begin{array}{c}0.57 \\
(0.498)\end{array}$ & $\begin{array}{c}0.35 \\
(0.476)\end{array}$ & $\begin{array}{c}0.70 \\
(0.458)\end{array}$ \\
\hline Location & kilometers & $\begin{array}{c}18.7 \\
(18.7)\end{array}$ & $\begin{array}{c}17.7 \\
(17.38)\end{array}$ & $\begin{array}{c}18.9 \\
(19.02)\end{array}$ & $\begin{array}{c}18.04 \\
(21.11)\end{array}$ & $\begin{array}{c}19.12 \\
(17.01)\end{array}$ \\
\hline Enterprise Age & Years & $\begin{array}{c}7.66 \\
(8.83)\end{array}$ & $\begin{array}{c}6.57 \\
(7.86)\end{array}$ & $\begin{array}{c}7.92 \\
(9.03)\end{array}$ & $\begin{array}{c}7.56 \\
(8.28)\end{array}$ & $\begin{array}{c}7.73 \\
(9.18)\end{array}$ \\
\hline Sector & $\begin{array}{c}\text { Dummy, } 1 \text { for trade/manufacturing, } \\
0 \text { for service }\end{array}$ & $\begin{array}{l}0.04 \\
(0.2)\end{array}$ & $\begin{array}{c}0.95 \\
(0.21)\end{array}$ & $\begin{array}{c}0.88 \\
(0.32)\end{array}$ & $\begin{array}{c}0.89 \\
(0.319)\end{array}$ & $\begin{array}{c}0.91 \\
(0.293)\end{array}$ \\
\hline
\end{tabular}

and liquidity non-constrained (39.6 years old). Marital status of this study was recorded at 80 percent of household heads that were married and was similarly reflected among the borrowers and liquidity non-constrained with 78 percent and 82 percent respectively. Anglewicz [32] also observed that it is universal for household heads to be married in Malawi. The household size had an average of 5 people for all the categories of borrowers and liquidity non-constrained. Education status of the household heads had a proportion of 50 percent to have attained at least primary education, indicating that a high proportion is illiterate. Similarly, 60 percent of the households categorized themselves as being poor, but the proportion decreased amongst the borrowers (53 percent) and liquidity non-constrained (35 percent). The locations of the households were calculated from the districts main trading area, which has banks and other MFIs. The FinScope 2008 survey found that most people who have bank accounts in Malawi use public transport to access the banks. This is supported in this study as an average distance between households and possible bank locations was $18.7 \mathrm{~km}$; suggesting that most of the respondents were located in rural areas.

\subsection{Determinants of Household Borrowing}

The logit model empirical results that estimated the factors influencing borrowing by households for business investment in Malawi are presented in Table 2. VIF values of the variables were calculated as a diagnostic test for the multicollineality, and this problem was not detected as all values had the accepted values of less than 10 . The model was rendered appropriate as its goodness of fit chi-square was significant showing that the model adequately fitted the data. The proportion of borrowers was at 19 percent, which resulted in lowly fitted model with data that explained 3 percent of the variation in the dependent variable. Thus care was needed in explaining the influence of the hypothesized independent variables.

In the estimated logit model (Table 2), age of household head, household size, Poverty status of household and enterprise sector were found to have statistically significant impact on the household decision to obtain credit for investing in their businesses. Household size, Poverty status of household and enterprise sector had a positive on household decision to borrow; while age of household head was found to have a negative impact on household's decision to borrow. In contrast, gender, marital status, education level attained by household heads, location of household and enterprise age was found not to be significant.

The estimated coefficient shows that the probability of borrowing money to invest in an enterprise by a household decreases with an increase in age of household head. The model decreases by 0.015 units with a negative 
Table 2. Results of the logit model of household's decision to borrow.

\begin{tabular}{|c|c|c|c|c|c|c|c|}
\hline Factors & Coefficient $(\beta)$ & Robust std error & $\mathbf{Z}$ & $\mathbf{P}>\mathbf{z}$ & Exponential $(\boldsymbol{\beta})$ & Marginal effect & VIF \\
\hline Gender & -0.098 & -0.294 & -0.33 & 0.739 & 0.907 & -0.015 & 2.62 \\
\hline Age & -0.015 & 0.007 & -2.14 & 0.032 & 0.985 & -0.002 & 2.48 \\
\hline Marital Status & -0.304 & 0.299 & -1.02 & 0.308 & 0.737 & -0.048 & 1.36 \\
\hline Household Size & 0.091 & 0.034 & 2.66 & 0.008 & 1.096 & 0.014 & 1.25 \\
\hline Education & -0.224 & 0.165 & -1.36 & 0.174 & 0.799 & -0.033 & 1.24 \\
\hline Poverty status & -0.264 & 0.156 & -1.69 & 0.090 & 0.768 & -0.039 & 1.21 \\
\hline Location & -0.004 & 0.004 & -1.06 & 0.287 & 0.996 & -0.001 & 1.12 \\
\hline Enterprise Age & -0.015 & 0.01 & -1.52 & 0.128 & 0.984 & -0.002 & 1.05 \\
\hline Sector & 1.02 & 0.326 & 3.13 & 0.002 & 2.77 & 0.117 & 1.01 \\
\hline Constant & -1.52 & 0.461 & -3.30 & 0.001 & 0.219 & & \\
\hline \multicolumn{2}{|c|}{ Number of Observations } & 1234 & & & & & \\
\hline \multicolumn{2}{|c|}{ Wald Chi-square (9) } & 32.43 & & & & & \\
\hline \multicolumn{2}{|c|}{ Prob > Chi-square } & 0.000 & & & & & \\
\hline \multicolumn{2}{|c|}{ Pseudo $\mathrm{R}^{2}$} & 0.0268 & & & & & \\
\hline \multicolumn{2}{|c|}{ Log Likelihood } & -588.884 & & & & & \\
\hline
\end{tabular}

marginal effect of 0.002 percent, as age of household head increases by a year; holding other factors at a fixed value. Exponential $(\beta)$ for age of household head shows that, holding other factors constant, the likelihood of borrowing by a household decreases by $0.015 \%$ for 1 year increase in age $(1-0.985=0.015)$. This is contrary to findings by Zeller [12] and Adesina [19] who found that the older a household head was, the likely they were to demand credit. However, these two studies focused on household's behavior to obtain credit for general household use or agriculture enterprise investment and not specifically for investment in a household non-agriculture enterprise, which is the central theme of this study. Thus the demand for credit in young household heads, shows how much capital is required to diverse the household's income sources. Furthermore, older households are most likely to have established the non-agriculture based enterprises and can use their savings acquired over a long period to invest in their businesses. Furthermore, Malawi being an agriculture based country household's led by older heads were more likely to have more resources, such as large farm land or herds of livestock, to diversify their sources of income.

Similarly the probability of borrowing money to invest in a non-agriculture enterprise by a household decreases with an increase in the self assessed poverty level of the household. The model decreases by 0.264 units with a negative marginal effect of 30 percent, as poverty level of household rises; holding other factors at a fixed value. The poor households in Malawi are characterized by low income levels and limited resources such as land for agriculture and material that can be used as collateral. $\mathrm{Li}$ [33] in the their paper that examined factors influencing accessibility of microcredit by rural households in China found that high income households often have more investment opportunities that demand credit and are confident in repaying if they borrow. Likewise, the poor in Malawi are would not be comfortable in borrowing as they do not have a second option incase loan repayment is impossible.

Impact of household size on decision to borrow money for investing in a household non-agriculture enterprise is found to be positive. The estimated coefficient indicates that household size has a positive effect on probability of borrowing with a positive marginal effect of 1.4 percent. Exponential of household size indicates that, with other factors being constant, the odds of borrowing increase by 9.6 percent as the size of household increases by one person. The finding corresponds with Wabei [23] and Ho [34] findings that large households are more likely to borrow. Larger households are unable to save funds for capital because of the large sized households exert pressure on the household financial resources. Additionally, large households may offer the household enterprise with human capital to enable it to grow quickly as such increasing demand for credit. 
Positive impact of enterprise sector (trading or manufacturing and service provision) is observed on the decision to borrow funds for capital with positive marginal effect of 11.7 percent. The model shows that increasing number of household enterprises specializing in production or retailing would also increase the need for borrowing capital to invest in their enterprise. Abdulsaleh and Worthington [9] point out that a manufacturing enterprise demands credit a long term period that is associated with breaking even in the production process, while services enterprises borrowing behavior responds to an immediate need. In Malawi government and non-governmental organizations programs that promote household non-agriculture enterprises focus on production type of endeavors, which makes it easy for micro-enterprises to demand credit. Thus it can be said that households venturing in service provision enterprises usually have the capital to fund all operations because they know how difficult it is to obtain loans; while the manufacturing enterprises begin their businesses with the hope of getting funds to support their investments.

\subsection{Determinants of Household Liquidity Constraint}

The empirical results for model that determined liquidity status among households that operate an enterprise are presented in Table 3. The model was rendered appropriate as its goodness of fit chi-square was significant showing that the model adequately fitted the data. The proportion of liquidity non-constrained households was at 39 percent, which resulted in lowly fitted model with data that explained 11.5 percent of the variation in the dependent variable. In the estimated logit model (Table 3), education level attained by household head and Poverty status of household were found to have statistically significant impact on the household being liquidity nonconstrained. Education level attained by household had a positive impact on a household being liquidity nonconstrained, while Poverty status of household was found to have a negative impact on a household being liquidity non-constrained. In contrast, gender, age, marital status, household size, location of household, enterprise sector and enterprise age was found not to be significant.

The estimated coefficient shows that the probability of a household being liquidity non-constrained decreases with the household being categorized as poor (poverty status). The model decreases with a negative marginal effect of 31.1 percent, as household Poverty status increases by becoming poorer; holding other factors at a fixed value. This study aimed at classifying households as borrowers and non-borrowers, but also classifies these households according to their liquidity status in which credit could be a component. The Poverty status of a household had significant influence on both borrowing and liquidity status, with a similar negative direction of

Table 3. Results of the logit model of determinants of household's liquidity status.

\begin{tabular}{|c|c|c|c|c|c|c|c|}
\hline Factors & Coefficient $(\beta)$ & Robust standard error & $\mathbf{Z}$ & $\mathbf{P}>\mathbf{z}$ & Exponential $(\beta)$ & Marginal effect & VIF \\
\hline Gender & 0.227 & 0.263 & 0.86 & 0.388 & 1.255 & 0.052 & 2.62 \\
\hline Age & -0.006 & 0.006 & -1.13 & 0.260 & 0.994 & -0.002 & 2.48 \\
\hline Marital Status & -0.197 & 0.263 & -0.75 & 0.454 & 0.821 & -0.047 & 1.36 \\
\hline Household Size & 0.006 & 0.030 & 0.20 & 0.841 & 1.001 & 0.001 & 1.25 \\
\hline Education & 0.711 & 0.138 & 5.14 & 0.000 & 2.036 & 0.166 & 1.24 \\
\hline Poverty Status & -1.334 & 0.131 & -10.22 & 0.000 & 0.263 & -0.309 & 1.21 \\
\hline Location & 0.004 & 0.003 & 1.15 & 0.250 & 1.004 & 0.001 & 1.12 \\
\hline Enterprise Age & 0.009 & 0.008 & 1.12 & 0.263 & 1.009 & 0.002 & 1.05 \\
\hline Sector & -0.223 & 0.206 & -1.08 & 0.279 & 0.800 & -0.053 & 1.01 \\
\hline Constant & 0.176 & 0.351 & 0.50 & 0.616 & 1.192 & & \\
\hline \multicolumn{2}{|c|}{ Number of Observations } & 1234 & & & & & \\
\hline \multicolumn{2}{|c|}{ Wald Chi-square (9) } & 190.0 & & & & & \\
\hline \multicolumn{2}{|c|}{ Prob $>$ Chi-square } & 0.000 & & & & & \\
\hline \multicolumn{2}{|c|}{ Pseudo $\mathrm{R}^{2}$} & 0.115 & & & & & \\
\hline \multicolumn{2}{|c|}{ Log Likelihood } & -730.077 & & & & & \\
\hline
\end{tabular}


influence in both models. The result indicates that the poor households lack funds to finance their enterprises and as such it increases their likelihood of borrowing funds as capital to invest in their enterprises. Cheng and Ahmed [10] emphasize on the need for MFI's to develop loan products that target the poorer households who can present a bigger market when considered at a larger scale. For a country that is poverty ridden like Malawi, the poorer households that are below the poverty line for the majority and investing in them is a scenario that can provide an option to poverty alleviation. Furthermore, a positive impact was observed on education attainment by household head had on liquidity constraint with positive marginal effect of 16.6 percent. Education attainment by household heads, which represent the influential members of a household, increases the likelihood of having better income sources than the non-educated. This shows that the more educated a household head is the less likely the house would be categorized as poor. Thus education increases the option of household head funding an enterprise using savings hence making education attainment not significant to borrowing (Table 3).

\section{Conclusions}

This study examined major factors that influenced households with non-agriculture enterprises to borrow funds as capital for their enterprises in Malawi. Additionally, the study aimed at classifying households as borrowers and non-borrowers, but also classified these households according to their liquidity status in which credit could be a component. Non-agriculture enterprises were considered as vital to diversifying household incomes for the poor who formed the majority in Malawi, a developing country. Literature reviewed in this paper identified three main groups of factors considered central to micro-enterprise studies that included demographic factors, social economic factors and enterprise characteristics. Specifically, the empirical analysis based on logit model analyzed influence on borrowing and liquidity status by factors that included gender, age and marital status household head, education attained by household head, size of household, poverty status of household, age of enterprise, location of household, and enterprise sector. Logit model results showed that borrowing was influenced by age of household head, size of household, poverty status of household and enterprise size. The results also indicated that liquidity status was influenced by education attained by household head and poverty status of household. Poverty status of the households was found to influence both borrowing and liquidity non-constraint of households in Malawi.

The findings of this study support the general observation that capital is a major limiting factor for development of household non-agriculture enterprises. The study shows that MFI's need to focus on poor households that are unable to support their enterprises with personal savings. Enterprises that can be targeted are those that are based on production and retailing of goods, because there is a willingness to invest in machinery and goods that can enable them break even in the production process. Breaking even will require that loan repayment is designed in such a way that repayment is spread across a long time period. Policy makers in Malawi must encourage and design programs that will provide credit to poor households to support non-agriculture enterprises. Consideration should be given to supporting loan repayment plans for households involved in the manufacturing sector, which have to be spread over a period to allow them to break even.

\section{References}

[1] Cant, G. and Obamuyi, T.M. (2009) Credit Delivery and Sustainability of Micro-Credit Schemes in Nigeria. Journal of Enterprising Communities: People and Places in the Global Economy, 3, 71-83. http://dx.doi.org/10.1108/17506200910943689

[2] Messah, O.B. and Wangai, P.N. (2011) Factors That Influence the Demand for Credit for Credit among Small-Scale Investors: A Case Study of Meru Central District, Kenya. Research Journal of Finance and Accounting, 2, 74-101.

[3] Mukherjee, S. and Benson, T. (2003) The Determinants of Poverty in Malawi, 1998. World Development, 31, $339-358$. http://dx.doi.org/10.1016/S0305-750X(02)00191-2

[4] Government of Malawi (2012) Financial Scope (Finscop) Micro, Small and Medium Enterprises Survey-Malawi 2012. Ministry of Industry and Trade, Lilongwe.

[5] Atieno, R. (2001) Formal and Informal Institutions’ Lending Policies and Access to Credit by Small-Scale Enterprises in Kenya: An Empirical Assessment. African Economic Research Consortium. http://dspace.africaportal.org/jspui/bitstream/123456789/32164/3/RP111.pdf?1

[6] Da Silva, G.J.C., Oreiro, J.L., de Paula, L.F. and Sobreira, R. (2007) Macroeconomic Determinants of Banking Spreads in Brazil: An Empirical Evaluation. http://www.anpec.org.br/encontro2007/artigos/A07A098.pdf 
[7] Wen, Y. (2015) Money, Liquidity and Welfare. European Economic Review, 76, 1-24. http://dx.doi.org/10.1016/j.euroecorev.2015.01.012

[8] Chirwa, E. (2002) Microfinance and Poverty Reduction in Malawi: What Has Happened to the Microfinance Revolution? Wadonda Consult Working Paper WC/01/02.

[9] Abdulsaleh, A.M. and Worthington, A.C. (2013) Small and Medium-Sized Enterprises Financing: A Review of Literature. International Journal of Business and Management, 8, 36-54. http://dx.doi.org/10.5539/ijbm.v8n14p36

[10] Cheng, E. and Ahmed, A. (2014) The Demand for Credit, Credit Rationing and the Role of Microfinance. China Agricultural Economic Review, 6, 295-315. http://dx.doi.org/10.1108/CAER-07-2012-0076

[11] Azevedo, J.P. (2006) Microfinance and Poor Entrepreneurs. International Handbook Series on Entrepreneurship, 3, 301-334. http://dx.doi.org/10.1007/978-0-387-32313-8 11

[12] Zeller, M. (1994) Determinants of Credit Rationing: A Study of Informal Lenders and Formal Credit Groups in Madagascar. World Development, 22, 1895-1907. http://dx.doi.org/10.1016/0305-750X(94)90181-3

[13] Jabbar, M.A., Ehui, S.K. and Von Kaufmann, R. (2002) Supply and Demand for Livestock Credit in Sub-Saharan Africa: Lessons for Designing New Credit Schemes. World Development, 30, 1029-1042. http://dx.doi.org/10.1016/S0305-750X(02)00021-9

[14] Rand, J. (2006) Credit Constraints and Determinants of the Cost of Capital in Vietnamese Manufacturing. Small Business Economics, 29, 1-13. http://dx.doi.org/10.1007/s11187-005-1161-2

[15] Togba, L.E. (2012) Microfinance and Households Access to Credit: Evidence from Côte D’ivoire. Structural Change and Economic Dynamics, 23, 473-486. http://dx.doi.org/10.1016/j.strueco.2012.08.002

[16] Fletschner, D. and Kenney, L. (2014) Rural Women’s Access to Financial Services: Credit, Savings, and Insurance, in Gender in Agriculture. Springer, Netherlands, 187-208. http://dx.doi.org/10.1007/978-94-017-8616-4_8

[17] Fabiyi, E.F. and Akande, K.E. (2015) Economic Empowerment for Rural Women in Nigeria: Poverty Alleviation through Agriculture. Journal of Agricultural Sciences, 7. http://dx.doi.org/10.5539/jas.v7n9p236

[18] Bendig, M., Giesbert, L. and Steiner, S. (2009) Savings, Credit and Insurance: Household Demand for Formal Financial Services in Rural Ghana. Germany Institute of Global and Area Studies (GIGA), Working Paper No. 94.

[19] Adesina, A.A., Mbila, D., Nkamleu, G.B. and Endamana, D. (2000) Econometric Analysis of the Determinants of Adoption of Alley Farming by Farmers in the Forest Zone of Southwest Cameroon. Agriculture, Ecosystems \& Environment, 80, 255-265. http://dx.doi.org/10.1016/S0167-8809(00)00152-3

[20] Ahmed, S.M., Chowdhury, M. and Bhuiya, A. (2001) Micro-Credit and Emotional Well-Being: Experience of Poor Rural Women from Matlab, Bangladesh. World Development, 29, 1957-1966. http://dx.doi.org/10.1016/S0305-750X(01)00069-9

[21] Asfaw, A. and Admassie, A. (2004) The Role of Education on the Adoption of Chemical Fertilizer under Different Socioeconomic Environments in Ethiopia. Agricultural Economics, 30, 215-228. http://dx.doi.org/10.1111/j.1574-0862.2004.tb00190.x

[22] Fanwell, B. (2001) Determinants and Characteristics of Household Demand for Smallholder Credit in Malawi. MA Thesis, University of Malawi, Malawi.

[23] Wabei, S. (2012) Determinants of Household Credit Demand in Zambia. MA Thesis, University of Zambia, Zambia. http://dspace.unza.zm:8080/xmlui/handle/123456789/3057

[24] Giné, X. and Yang, D. (2009) Insurance, Credit, and Technology Adoption: Field Experimental Evidence from Malawi. Journal of Development Economics, 89, 1-11. http://dx.doi.org/10.1016/j.jdeveco.2008.09.007

[25] Quartey, P. (2003) Financing Small and Medium Enterprises (SMEs) in Ghana. Journal of African Business, 4, 37-55. http://dx.doi.org/10.1300/J156v04n01_03

[26] Fatoki, O.O. and Asah, F. (2011) The Impact of Firm and Entrepreneurial Characteristics on Access to Debt Finance by SMEs in King Williams’ Town, South Africa. International Journal of Business and Management, 6, 170-179. http://dx.doi.org/10.5539/ijbm.v6n8p170

[27] Zeitun, R. and Tian, G.G. (2014) Capital Structure and Corporate Performance: Evidence from Jordan. Australasian Accounting Business \& Finance Journal. http://dx.doi.org/10.2139/ssrn.2496174

[28] Abor, J. (2008) Determinants of the Capital Structure of Ghanaian Firms. African Economic Research Consortium. http://dspace.africaportal.org/jspui/bitstream/123456789/32100/1/RP176.pdf?1

[29] John, R. (2007) Credit Constraints and Determinants of the Cost of Capital in Vietnamese Manufacturing. Small Business Economics, 29, 1-13. http://dx.doi.org/10.1007/s11187-005-1161-2

[30] Goswami, K., Choudhury, H.K. and Saikia, J. (2012) Factors Influencing Farmers’ Adoption of Slash and Burn Agriculture in North East India. Forest Policy and Economics, 15, 146-151. http://dx.doi.org/10.1016/j.forpol.2011.11.005 
[31] Gujarati, D.N. (2004) Basic Econometrics. 4th Edition, Tata McGraw-Hill, New York.

[32] Anglewicz, P. (2012) Migration, Marital Change, and HIV Infection in Malawi. Demography, 49, 239-265. http://dx.doi.org/10.1007/s13524-011-0072-x

[33] Li, X., Gan, C. and Hu, B. (2011) Accessibility to Microcredit by Chinese Rural Households. Journal of Asian Economics, 22, 235-246. http://dx.doi.org/10.1016/j.asieco.2011.01.004

[34] Ho, G. (2004) Rural Credit Markets in Vietnam: Theory and Practice. Department of Economics, Macalester College. https://www.mpls.frb.org/ /media/files/mea/contest/2004papers/ho.pdf?la=en 